\title{
Hysteresis-based Voltage and Current Control Techniques for Grid Connected Solar Photovoltaic Systems: Comparative Study
}

\author{
S. Raja Mohamed ${ }^{1}$, P. Aruna Jeyanthy ${ }^{2}$, D. Devaraj ${ }^{3}$ \\ ${ }^{1}$ Department of Electrical and Computer Engineering, King Faisal University, Saudi Arabia \\ ${ }^{2,3}$ Department of Electrical Engineering, Kalashalingham University, India
}

\begin{tabular}{l} 
Article Info \\
\hline Article history: \\
Received Oct 3, 2017 \\
Revised Dec 31, 2017 \\
Accepted Aug 20, 2018 \\
\hline
\end{tabular}

Keyword:

Hysteresis controller Power quality Solar photovoltaic system Total harmonic distortion Voltage source inverter

\begin{abstract}
Solar PV system development and integration with existing grid is very fast in recent years all over the world, as they require limited maintenance, pollution free and simple structure. When observing the factors affecting the performance of the grid connected solar photovoltaic system, the inverter output voltage with harmonics add with the harmonics generated due to the non-linear loads, retain a bigger challenge to maintain power quality in the grid. To maintain grid power quality, better inverter control technique should be developed. This paper presents the two control techniques for grid-tied inverters. This study developed the hysteresis controller for the inverter. Hysteresis controller used in this work two way (i) Voltage control mode (ii) Current control mode. Matlab/Simulink model is developed for the proposed system. Further the study presents the comparative evaluation of the performance of both control techniques based on the percentage of total harmonic distortion (THD) with the limits specified by the standards such as IEEE 1547 and IEC 61727 and IEEE Std 519-2014.
\end{abstract}

Copyright (c) 2018 Institute of Advanced Engineering and Science. All rights reserved.

\section{Corresponding Author:}

S. Raja Mohamed,

Department of Electrical and Computer Engineering,

King Faisal University,

PO Box: 380; PC-31982-Hofuf, Al-Hasa, Saudi Arabia.

Email: rsumsudeen@kfu.edu.sa

\section{INTRODUCTION}

Due to the limited fossil fuel reserve availability, global warming and increasing the fuel cost, all the countries turn towards to use of green energy sources, such as wind energy bio-energy and photovoltaic energy, fuel cell etc. Among the various types of Distributed generation (DG) systems, solar PV system development is very fast in recent years, as they require limited maintenance, pollution free and simple structure. While Solar PV has many advantages at the same time, it also poses several challenges, like when increase the penetration of solar PV system into the existing grid, many problems created for example instability, increase harmonics level, voltage variation and flicker etc. Harmonics is found to be most important problem out all the above issues related to the quality power inject into the grid. Considering the above reasons there is an essential to develop novel inverter topology and controller to improve the quality of solar energy produced [1]. In [2] authors have presented the comparison of sinusoidal PWM voltage and hysteresis current control methods of grid-tied inverters act as a reactive power compensator.

The results conclude that, when switching frequency of the inverter is low, remove the unwanted ripples of the output current is more difficult task. For this reasons voltage control technique is preferred. In [3] presents a current control loop mechanism in 3-phase inverter which is used to control the reactive and active power as well as maintain the good power quality. But, the study found that proposed current control performance is affected often by change of magnitude, frequency, voltage dips, transient issues occur in a 3- 
phase grid. The study recommended that further enhancements to the current loop can be made by using soft computing and intelligent control schemes. In [4] a hybrid model predictive control (HMPC) system is proposed to control a 2-level voltage source inverter (VSI) of the high power grid. The impacts of the modelling error on the system stability and average switching frequency are analyzed. HMPC can keep the average switching frequency maintain operational limit, whereas improving the stability. Modelling and analysis of a grid connected solar PV system integrating shunt active power filter (APF) with different PWM generation feeding the nonlinear load is presented in [5]. In this study to generate required PWM signal for the inverter hysteresis current control and space vector modulation (SVPWM) control are employed. The simulation result shows that SVPWM provide the better result. In [6] presents the performance of grid connected inverter with three digital hysteresis controllers such as fixed and adjustable switching frequency controllers and PI compensation loop. The study found that PI control loop is efficent method to reduce the harmonics Since, fixed switching frequency controller, the sampling frequency, filter inductance hystresis band parameters are influence on the output current harmonics of the system. In [7] presents the method to mitigate the power quality problems voltage sag, voltage swell of the grid by hysteresis voltage control technique is used in inverter of dynamic voltage restorer (DVR) with PV system. The study [8] propose the adaptive hysteresis band current control method for the 5-level cascaded multilevel inverter connected photovoltaic system. The study concluded that due to increasing the number of levels of the inverter further reduces total harmonic distortion (THD) of the system.

The study [9] proposed the fuzzy as well as adaptive controller to control the inverter used in the grid connected solar PV system. The study concluded that the fuzzy adaptive hysteresis current controller results in acceptable switching frequency and limited harmonic content and is suitable for photovoltaic system. In [10] presents the effect of solar irradiance frequent changes of the grid-connected PV System on THD. The study found that THD value increases when irradiance levels are decreasing. Unlike the above mentioned works, this paper investigate the performance of the grid connected solar PV system using hysteresis based voltage and current control techniques under the variable irradiance and temperature conditions. This paper is organized as follows. Section II detail explanation of the overview of the system. Section III presents modelling of various components in the system. The details of the proposed controller are given in section IV, Simulation results and analysis of the proposed system are given in section V. Conclusions are drawn in section VI.

\section{STRUCTURE OF GRID-TIED PV SYSTEM}

A grid-tied PV system as shown in Figure 1 have four major components blocks are there (i) solar PV array, (ii) power electronics interface (iii) Controller (iv) grid. The Solar PV array delivers variable DC power to the DC-DC boost converter, boosted DC power convert into the AC power using inverter and transfer to the grid. The both the power converters have separate control system for maximize the DC power and synchronous the grid and inverter voltage and frequencies.

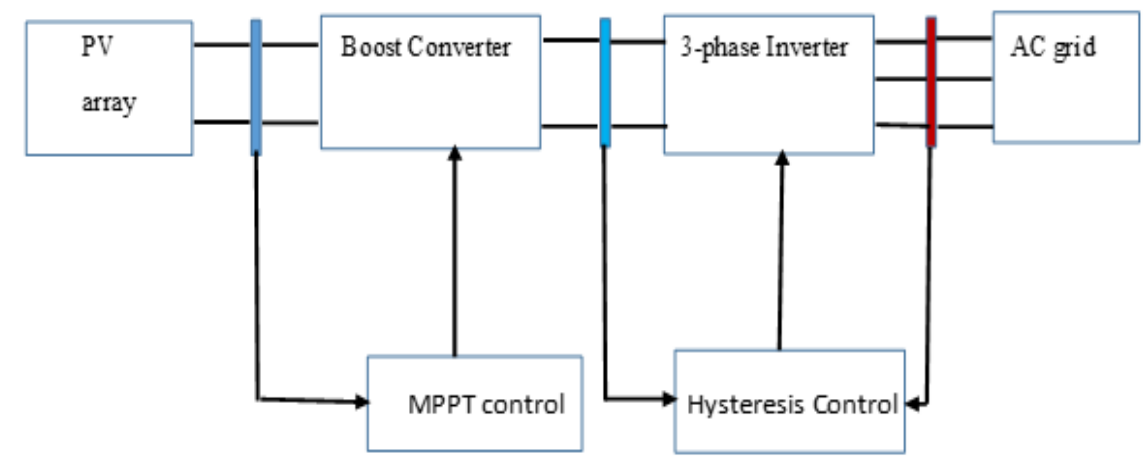

Figure 1. Grid-tied solar PV system

3. SYSTEM MODELLING

3.1. PV Array Model

The equiavalent circuit of the solar PV cell as illustration in Figure 2. 


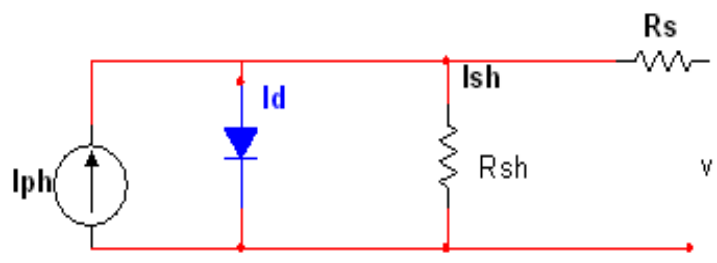

Figure 2. Equivalent circuit of a solar PV cell

PV cell equation is as shown in equation 1 ,

$$
I=I_{p h}-I_{0}\left\{e^{\left(\frac{q(v+R s I)}{A K T}-1\right)}\right\}-\left(\frac{V+R s I}{R s h}\right)
$$

where Id-reverse saturation diode current; v-thermal voltage; $\mathrm{N}$ diode quality factor; Iph photo voltaic current. The proportion of the photovoltaic current and light intensity as given in equation 2 .

$$
I p h=I_{r}\left(I_{p h o / I_{r o}}\right)
$$

where $I_{p h 0}$ is photo voltaic current under standard light intensity $\left(\mathrm{I}_{\mathrm{r} 0}\right)$ [11]. Solar PV cell Characteristic curves are shown in Figure 3.

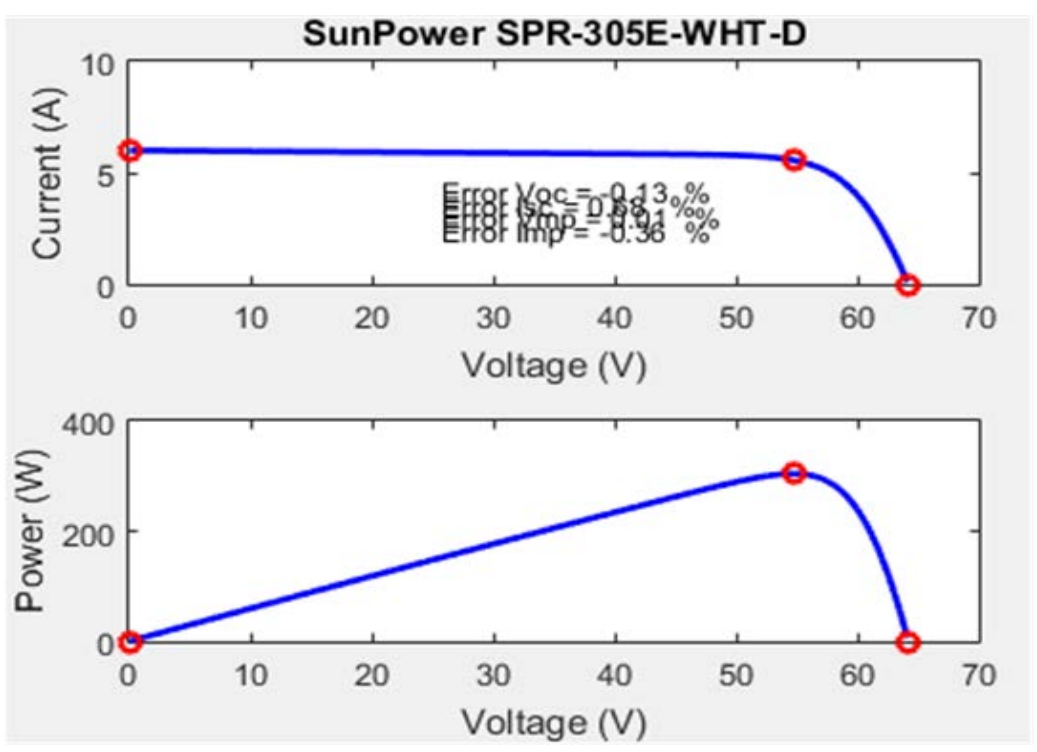

Figure 3. PV cell characteristics curve

\subsection{Boost Converter Model}

A simple boost Converter is as shown in Figure 4. It is used in solar PV system to boost the output voltage, when panel generate the lesser than actual voltage (unregulated) during the irregular weather conditions with help of maximum power point tracking techniques [12]. Under steady state operation,

$$
\begin{aligned}
& v_{\text {in }} \times t_{\text {on }}-\left(v_{0}-v_{\text {in }}\right) \times t_{\text {off }}=0 \\
& v_{\text {in }} \times D \times T=\left(v_{0}-v_{\text {in }}\right) \times(1-D) \times T \\
& \frac{v_{0}}{v_{\text {in }}}=\frac{1}{(1-D)}
\end{aligned}
$$




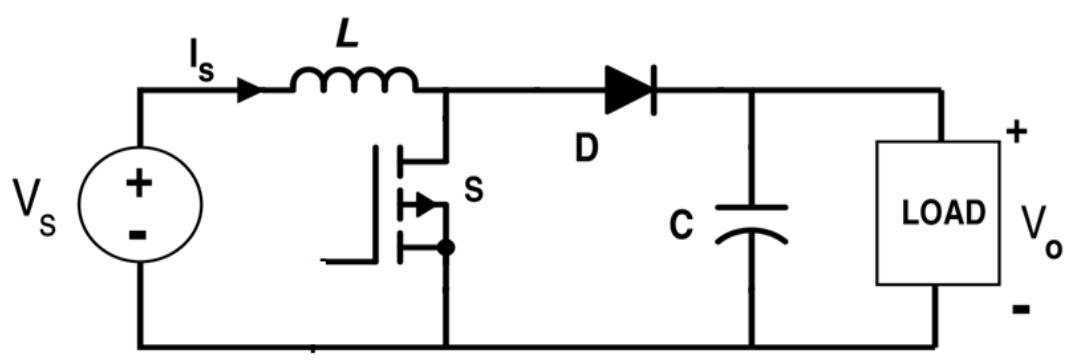

Figure 4. DC-DC boost converter [11]

\subsection{Three-Phase Voltage Source Inverter (VSI) Model}

The schematic diagram for a basic 3-phase VSI as shown in Figure 5. Here inverter is to convert dc voltage get from the solar PV cell via boost converter into the ac voltage. The inverter mathematical model state-space equations are given in Equation 6.

$$
\begin{aligned}
\left(\begin{array}{l}
\frac{d i_{A}}{d t} \\
\frac{d i_{B}}{d t} \\
\frac{d i_{C}}{d t}
\end{array}\right)=\left(\begin{array}{ccc}
-\mathrm{R} / \mathrm{L} & 0 & 0 \\
0 & -\mathrm{R} / \mathrm{L} & 0 \\
0 & 0 & -\mathrm{R} / \mathrm{L}
\end{array}\right)\left(\begin{array}{c}
i_{A} \\
i_{B} \\
i_{C}
\end{array}\right)+\left(\begin{array}{ccc}
1 / \mathrm{L} & 0 & 0 \\
0 & 1 / \mathrm{L} & 0 \\
0 & 0
\end{array}\right)\left(\begin{array}{l}
\mathrm{u}_{\mathrm{A}}-\mathrm{e}_{\mathrm{A}}-\mathrm{u}_{\mathrm{no}} \\
\mathrm{u}_{\mathrm{B}}-\mathrm{e}_{\mathrm{B}}-\mathrm{u}_{\mathrm{no}} \\
\mathrm{u}_{\mathrm{C}}-\mathrm{e}_{\mathrm{C}}-\mathrm{u}_{\mathrm{no}}
\end{array}\right) \\
u_{n o}=\left(u_{A}+u_{B}+u_{C}\right) / 3
\end{aligned}
$$

$u_{A}, u_{B}$ and $u_{c}$ are controlled with switching conditions (Si) according to equ (8). [12]

$$
u_{i}=S_{i} \times V_{d c}=\left\{\begin{array}{cc}
V_{d c}, & S_{i}=1 \\
0 & S_{i}=0
\end{array}\right.
$$

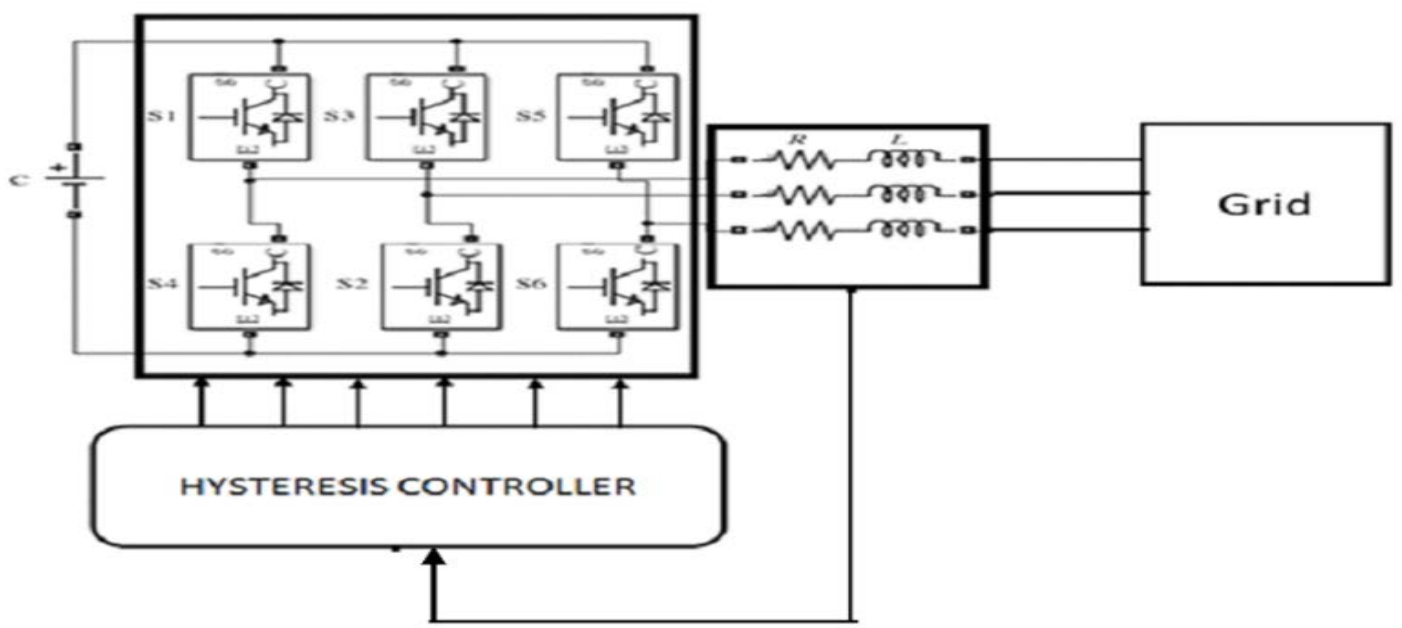

Figure 5. Schematic diagram of the 3-phase voltage source inverter with hysteresis controller [13] 


\section{CONTROLLERS DESIGN}

\subsection{MPPT Control Technique}

Incremental Conductance (IC) type MPPT techniques is developed based on P-V characteristic curve. During the vast irradiation changes environment other MPPT techniques are fail to track the maximum power. This problem solved by the IC method, it produces more energy and enhance the tracking time. Figure 6 illustrate the IC method MPPT procedure. [14-15]. Equation 9, 10 and 11 show the mathematical equation of the IC method. Maximum power condition is $\mathrm{dp} / \mathrm{dv}=0$

$$
\begin{aligned}
& \text { Power }=\mathrm{v}^{* \mathrm{i}} \\
& \mathrm{d}(\mathrm{v} * \mathrm{i}) / \mathrm{dv}=\mathrm{i}+\mathrm{v}^{*} \mathrm{di} / \mathrm{dv}=0 \\
& \mathrm{di} / \mathrm{dv}=-\mathrm{i} / \mathrm{v}
\end{aligned}
$$

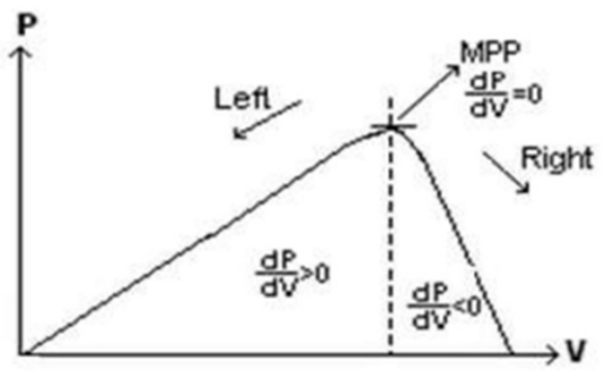

Figure 6.Incremental conductance MPPT[14-15]

\subsection{Hysteresis Control Techniques}

Hysteresis controller designed based on the properly selected hysteresis band (HB) fixed both of side of the signal representing the preferred output waveform. Actually the control circuit generates the desired magnitude and frequency reference sine wave signal, and it is compared with the actual input signal by using the comparator. Switch status as shown in Table 1.

Table 1. 3-Phase Inverter Switching Logic Based on Hysteresis band (HB)

\begin{tabular}{cc}
\hline Comparator output signal status & Switch Status \\
\hline Exceeds the upper band of HB & $\begin{array}{c}\text { Upper switch of the leg is ON; } \\
\text { Lower switch of the leg OFF } \\
\text { Cross the lower limits of HB }\end{array}$ \\
$\begin{array}{c}\text { Upper switch of the leg is OFF; } \\
\text { Lower switch of the leg is ON }\end{array}$ \\
\hline
\end{tabular}

This study two types of hysteresis based control techniques are applied (I) Hysteresis voltage control (HVC) (ii) Hysteresis current control (HCC) for the performance evaluation of the grid-tied PV system. This study two types of hysteresis based control techniques are applied (a) Hysteresis voltage control (HVC) (b) Hysteresis current control (HCC) for the performance evaluation of the grid-tied PV system.

\subsubsection{Hysteresis Voltage Control (HVC)}

Hysteresis voltage control structure as shown in Figure 7. In this technique grid-PCC point phase voltage measure and compare with reference voltage value, hysteresis voltage band desired based on the $\Delta \mathrm{v}$ error value. If suppose $\Delta$ error reach upper band value lower IGBTs are ON, alternate the $\Delta$ error reach lower band upper level IGBT are ON. Hysteresis band voltage control as shown in Figure 7. The relation between the switching frequency and hysteresis band as shown in equation 12

$$
T_{1}+T_{2}=T_{C}=1 / f_{c}(12)
$$

Here, Hysteresis band=VH-VL as shown in Figure 8 and the THD calculation as shown in Equation 13. 


$$
\operatorname{THD}(\%)=100 \times\left(\sqrt{\sum_{k=2}^{n} v_{k}} / v_{1}\right)
$$

Where: $\mathrm{K}=$ order of the harmonics.

$\mathrm{V} 1=$ fundamental component voltage

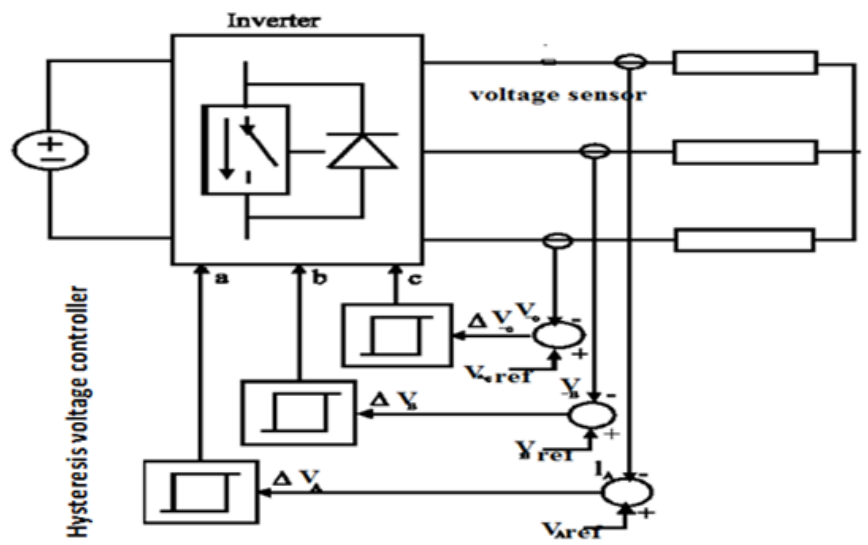

Figure 7. Hysteresis voltage controller connected to the network

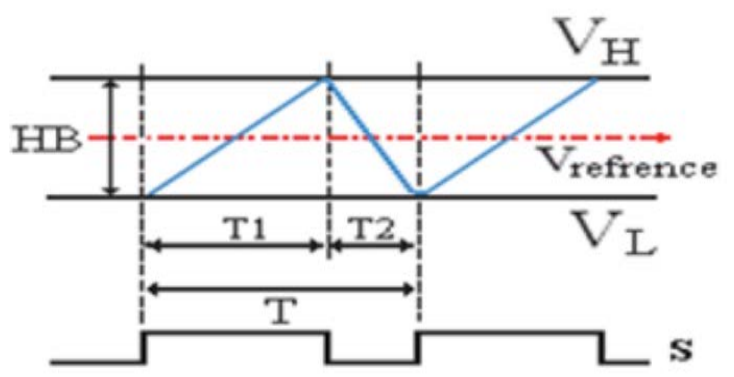

Figure 8. Hysteresis band voltage control

\subsubsection{Hysteresis Current Control (HCC)}

The HCC structure as shown in Figure 9. In this technique grid-PCC point phase current measure and compare with reference current value, hysteresis current band desired based on the $\Delta \mathrm{I}$-error value. If suppose $\Delta \mathrm{I}$ _error reach upper band value lower IGBTs are ON, alternate the $\Delta$ I_error reach lower band upper level $\overline{I G B T}$ are ON.

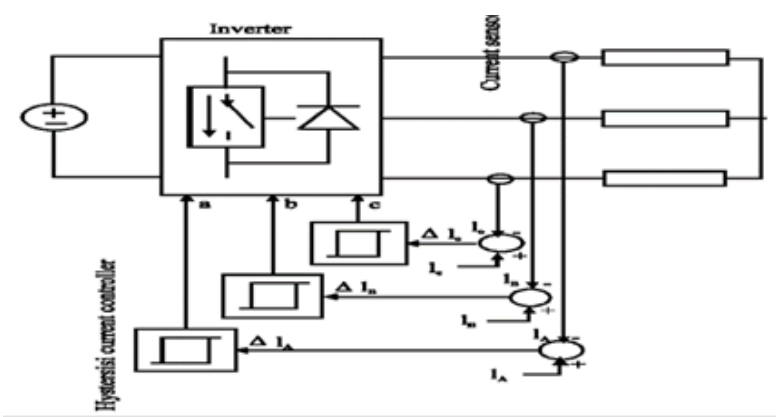

Figure 9. Hysteresis current controller connected to the network 


\section{RESULTS AND DISCUSSION}

The study model was developed and simulated using Simulink toolbox. The PV array is built based on the Table 2 data's and input signal temperature and irradiations ranges are set $25^{\circ} \mathrm{C}$ to $50^{\circ} \mathrm{C}$ and 250 to $1,000 \mathrm{~W} / \mathrm{m} 2$ respectively. The developed study case Simulink model simulated and tested with proposed two hysteresis control techniques (HCC and HVC) details are explain in this section.

Case.1: HCC controlled inverter connected solar PV system was simulated. The inverter output voltage, current and input voltage is shown in Figure 10. It's clearly indicate that the inverter output current signal is more distorted. THD of the voltage in this case is $0.28 \%$ and current is $42.42 \%$ as shown in Figure 11 and 12. The obtained results clearly indicate that voltage THD is within the IEEE-519-2014, IEEE-1547 and IEC61727 standards THD maximum limit 5\% [16], [17], [18]. However, the current THD is exceed the standards THD limit. The behaviour of the HCC control technique is found to be worst. Since hysteresis current control, harmonics are wide spread from low to high frequency range.

\begin{tabular}{cc} 
Table 2. The Description of Study Case Solar PV System \\
\hline Parameters & Specifications \\
\hline PV Array Data & Parallel string=7 \\
PV Module Data & Series connected modules per string=5 \\
Cells per module( $\mathrm{N}_{\text {cell }}$ ) & Name: Sun Power SPR-305-WHT-D \\
Maximum power $(\mathrm{W})$ & 96 \\
OCC voltage $($ Voc) $(\mathrm{V})$ & $305.226 \mathrm{w}$ \\
SCC current $\left(\mathrm{I}_{\mathrm{sc}}\right)(\mathrm{A})$ & $64.2 \mathrm{~V}$ \\
& $5.96 \mathrm{~A}$ \\
\hline
\end{tabular}

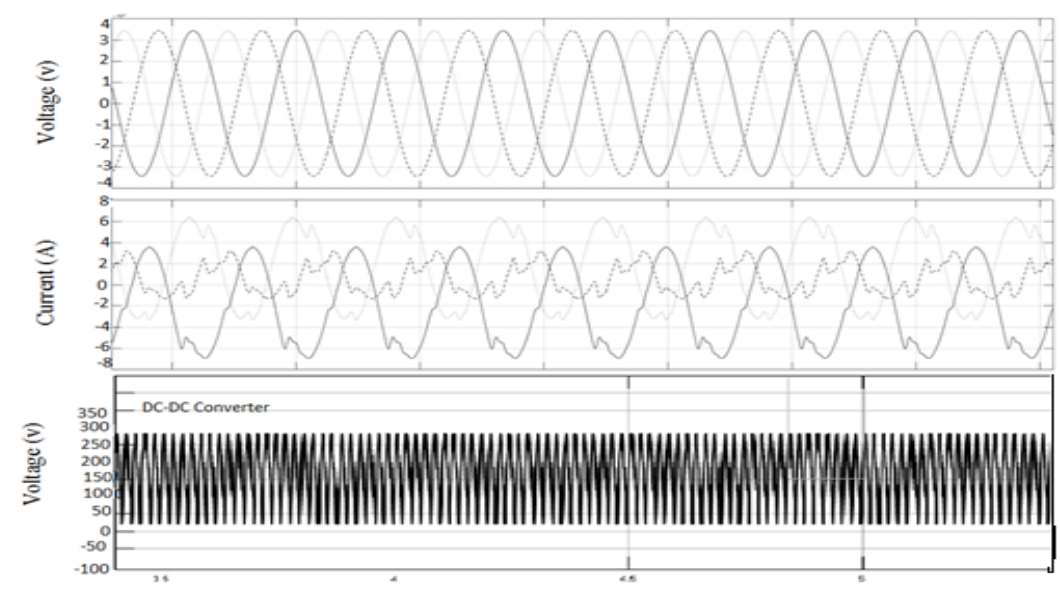

Figure 10. Inverter output voltage, output current and input voltage (HCC control)

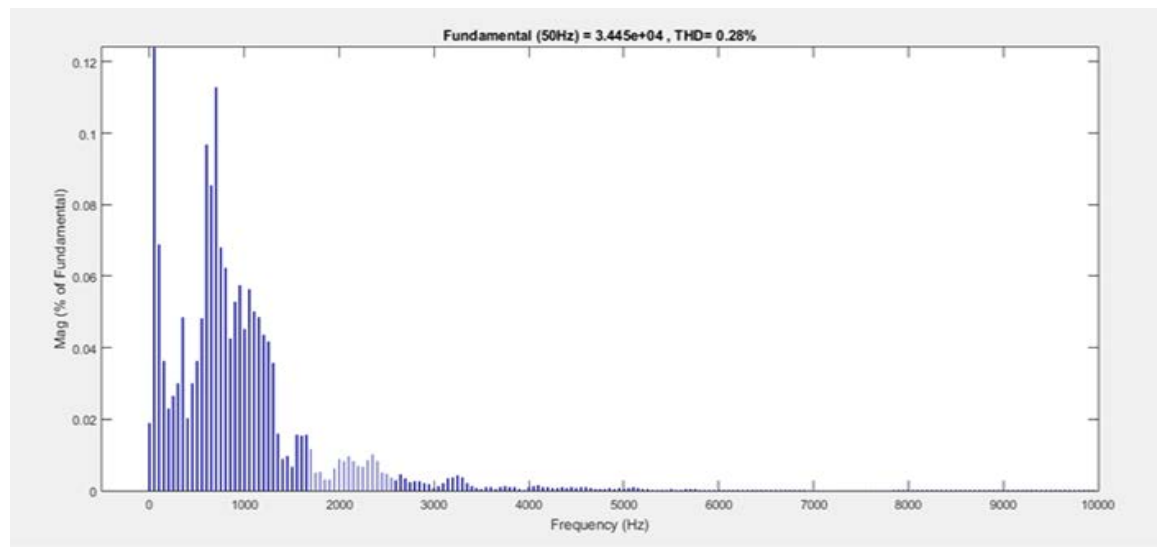

Figure 11. Voltage THD (V_THD)-Case 1 


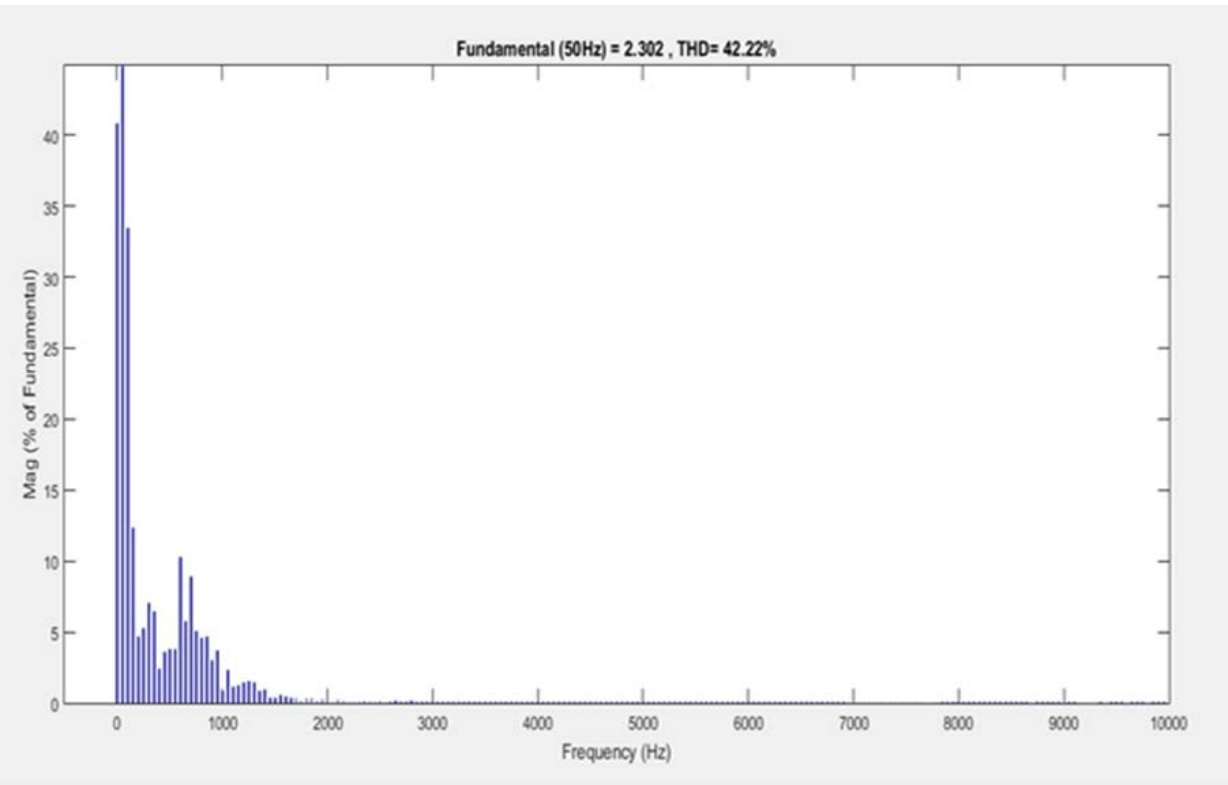

Figure 12. Current THD (I_THD) - Case 1

Case 2: HVC controlled inverter connected solar PV system was simulated. Figure 13 shows the inverter output voltage, current and input voltage. It's clearly show that the current signal less oscillation. THD of the voltage is this case is $0.17 \%$ and current is 3\% as shown in Figure 14 and 15. This THD values are within the THD limit of IEEE-519-2014, IEEE 1547 and IEC-61727 standards. The operation of the HVC control technique is found to be much better than HCC control.
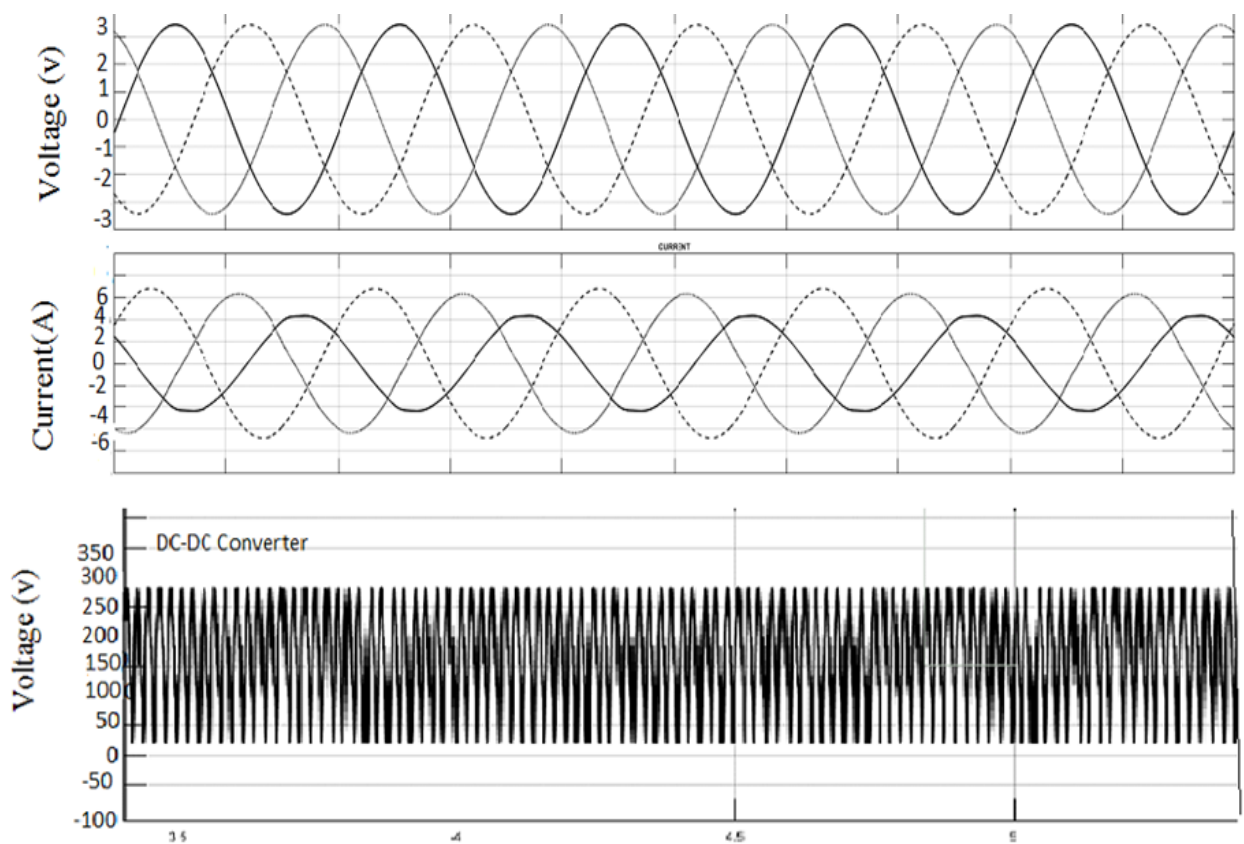

Figure 13. Inverter voltage, current and DC-DC converter output voltage-Case 2

The voltage and current THD with constant switching frequency of two hysteresis controllers are given in Table 3. The comparison of two hysteresis control techniques with different order of harmonics and maximum current THD are summarized in Table 4. The current THD value of the 3rd -9th harmonic order 
and 11 th -15 th of the HVC controller is $3 \%$ and $0.25 \%$ respectively and it meets the standard, at the same harmonic orders HCC controller is generated $40 \%$ and $5 \%$ of THD, it's not satisfied the standards. Also the harmonic order 17th -21st and 23rd -33rd current harmonics of the HVC controller not appear and HCC controller is generate the $3.5 \%$ and $2.5 \%$ THD, it is not within the standard values $1.5 \%$ and $0.6 \%$.

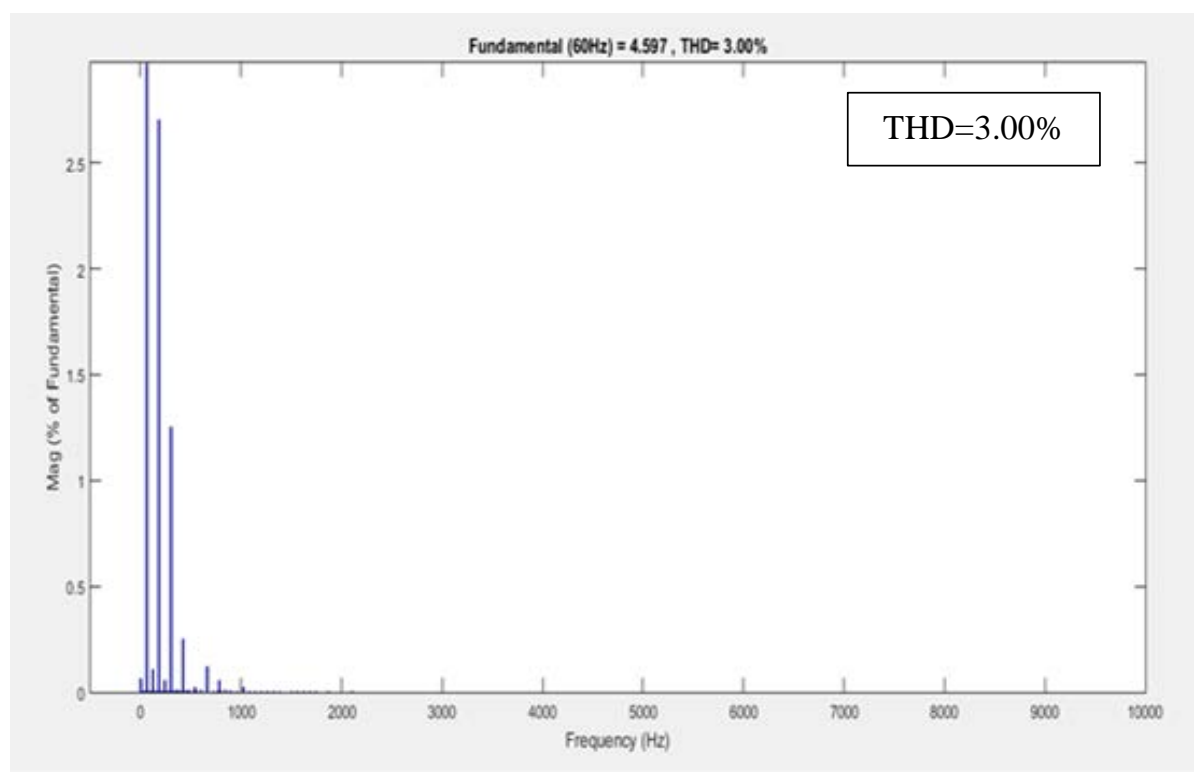

Figure 14. Current THD (I_THD)-Case 2

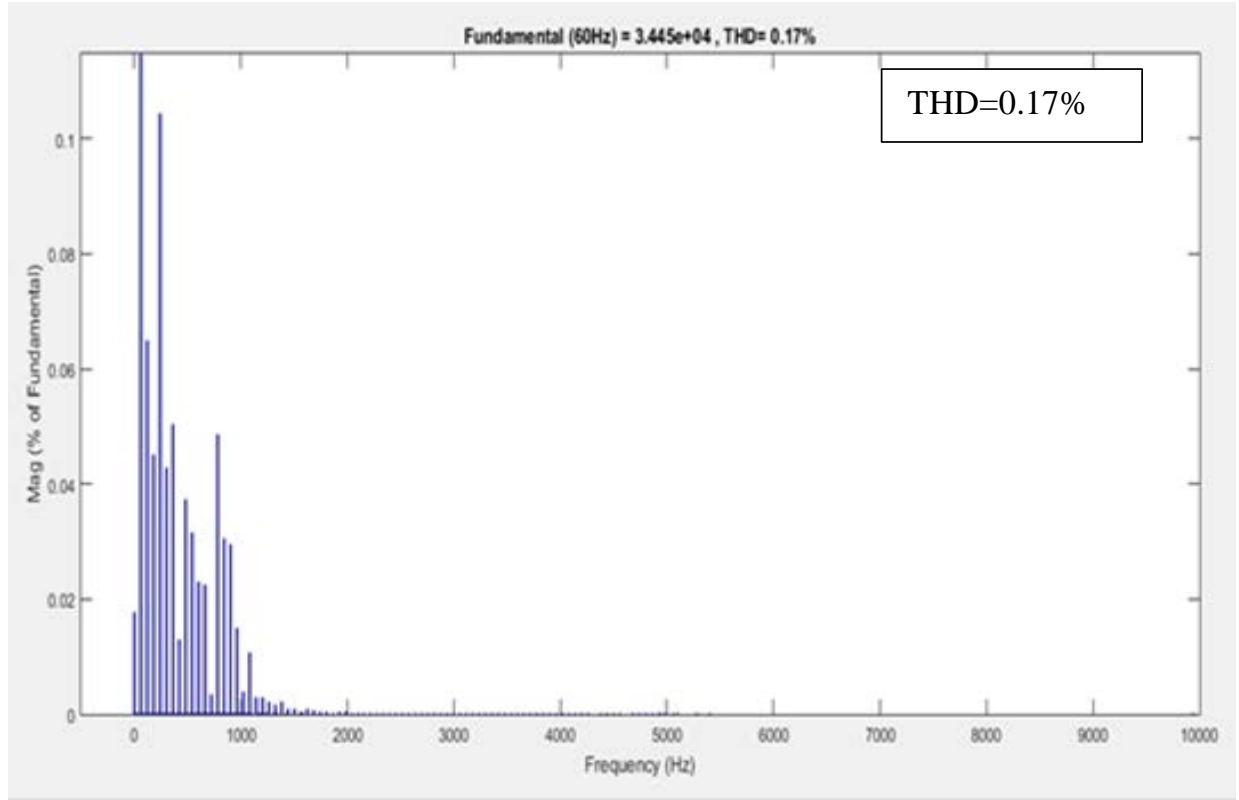

Figure 15. Voltage THD (V_THD)- Case 2

Table 3. Comparison of Two Hysteresis Control Techniques

\begin{tabular}{cccc}
\hline Controller & Current (\%THD) & Voltage (\%THD) & $\begin{array}{c}\text { Switching } \\
\text { frequency (kHz) }\end{array}$ \\
\hline Hysteresis- Current Control (HCC) & $42.22 \%$ & $0.28 \%$ & 10 \\
Hysteresis-voltage control (HVC) & $3.00 \%$ & $0.17 \%$ & 10 \\
\hline
\end{tabular}


Table 4. Comparison of Two Hysteresis Control Techniques with Order of the Harmonics

\begin{tabular}{|c|c|c|c|c|c|c|}
\hline & \multicolumn{2}{|c|}{ IEC-61727 Standard } & \multicolumn{2}{|c|}{ Study system with (HVC) } & \multicolumn{2}{|c|}{$\begin{array}{c}\text { Study system with } \\
\text { (HCC) }\end{array}$} \\
\hline \multirow[t]{2}{*}{ Nominal Power } & \multicolumn{2}{|c|}{$10 \mathrm{KW}$} & \multicolumn{2}{|c|}{$10 \mathrm{KW}$} & \multicolumn{2}{|c|}{$10 \mathrm{KW}$} \\
\hline & $\begin{array}{c}{ }^{*} \mathrm{H} \\
\left(\mathrm{n}^{\mathrm{th}}\right)\end{array}$ & THD (\%) & $\begin{array}{c}{ }^{*} \mathrm{H} \\
\text { (nth) }\end{array}$ & $\begin{array}{l}\text { THD } \\
(\%)\end{array}$ & $\begin{array}{c}{ }^{*} \mathrm{H} \\
\text { (nth) }\end{array}$ & $\begin{array}{l}\text { THD } \\
(\%)\end{array}$ \\
\hline \multirow{4}{*}{$\begin{array}{l}\text { Harmonic current } \\
\text { limits }\end{array}$} & $3-9$ & 4 & $3-9$ & $3 \%$ & $3-9$ & 40 \\
\hline & $11-15$ & 2 & $11-15$ & $0.25 \%$ & $11-15$ & 5 \\
\hline & $17-21$ & 1.5 & Not appear & -- & $17-21$ & 3.5 \\
\hline & $23-33$ & 0.6 & Not appear & -- & $23-33$ & 2.5 \\
\hline $\begin{array}{c}\text { Maximum current } \\
\text { THD }\end{array}$ & \multicolumn{2}{|c|}{$5 \%$} & \multicolumn{2}{|c|}{$3 \%$} & & $42.42 \%$ \\
\hline
\end{tabular}

\section{CONCLUSION}

The performance of the two proposed controller techniques: hysteresis voltage controller and hysteresis current controller has been investigated. The PV array modelling, inverter circuit topology, control algorithm and implementation procedures are analyzed in detail. The competency of the proposed hysteresis controllers has been demonstrated through the results of the simulation and validated with the IEEE 5192014, IEEE-1547 and IEC-61727 standards. This study concludes based on the results HVC controller used in inverter is suitable for grid connected solar photovoltaic system to avoid the power quality problem

\section{REFERENCES}

[1] A. Rajapakse, D. Muthumuni, and N. Perera.Grid integration of renewable energy systems.in Renewable Energy, InTech.2009:109-131.

[2] Porasad Y, Hosseinzadeh H. Comparison of voltage control and current control methods in grid connected inverters. Journal of Applied Sciences. 2008;8(4):648-53.

[3] A F Jabbar, M Mansor.Current control loop of 3 phase grid-connected inverter. IOP Conference Series: Earth and Environmental Science.2013.

[4] Arul Kumar K, Vijayakumar D, Palanisamy K. Recent advances and control techniques in grid connected PV system. A review. International Journal of Renewable Energy Research (IJRER). 2016 Sep 6;6(3):1037-49.

[5] Ibrahim Z, et al., Performance investigation of photovoltaic grid connection for shunt active power filter with different pwm generation. Journal of Theoretical \& Applied Information Technology. 2013 Nov 20;57(2).

[6] Elsaharty MA, Hamad MS, Ashour HA. Digital hysteresis current control for grid-connected converters with LCL filter. IECON 2011-37th Annual Conference on IEEE Industrial Electronics Society 2011 Nov 7 (pp. 4685-4690).

[7] Ali SY, Suneeta K. Simulation of the hysteresis voltage control technique in the pv based dynamic voltage restorer for power quality improvement with induction motor drive. International Journal of Electrical and Electronics Engineering Research (IJEEER).2015;5(1) :95-106.

[8] Punitha K, Devaraj D, Sakthivel S. Adaptive hysteresis current control of inverter for solar photovoltaic applications. International Journal of Innovative Technology \& Creative Engineering. 2011 Mar 3;1(3):25-33.

[9] Devaraj D, Sakthivel S, Punitha K. Fuzzy adaptive hysteresis band current controller for solar photovoltaic inverter. In Advanced Materials Research 2012 (Vol. 403, pp. 4991-4999). Trans Tech Publications.

[10] Ayub M, Gan CK, Kadir AF. The impact of grid-connected PV systems on Harmonic Distortion. In Innovative Smart Grid Technologies-Asia (ISGT Asia), IEEE 2014 May 20: 669-674).

[11] Louzazni M, Aroudam EH, Yatimi H. Modeling and simulation of a solar power source for a clean energy without pollution. International Journal of Electrical and Computer Engineering. 2013 Aug 1;3(4):568.

[12] Erickson RW, Maksimovic D. Fundamentals of power electronics. Springer Science \& Business Media; 2007.

[13] Isen E, Bakan AF. Comparison of hysteresis controlled three-wire and split-link four-wire grid connected inverters. In Electrical Engineering/Electronics, Computer, Telecommunications and Information Technology (ECTI-CON), 2011 8th International Conference on 2011 May 17:727-730.

[14] Selvan S, Nair P, Umayal U. A Review on Photo Voltaic MPPT Algorithms. International Journal of Electrical and Computer Engineering. 2016 Apr 1;6(2):567.

[15] Nandurkar SR, Rajeev M. Design and Simulation of Three Phase Inverter for Grid Connected Photovoltaic systems. In 23rd annual IEEE Applied Power Electronics Conference and Exposition,2012:80-83.

[16] Langella R, Testa A. IEEE Recommended Practice and Requirements for Harmonic Control in Electric Power Systems.

[17] IEEE Standards Association. IEEE 1547 standard for interconnecting distributed resources with electric power systems. IEEE Standards Association, Piscataway. 2003.

[18] Photovoltaic IE. Systems. Characteristics of the Utility Interface. IEC Std. 2004 Jan: 61:727. 


\section{BIOGRAPHIES OF AUTHORS}

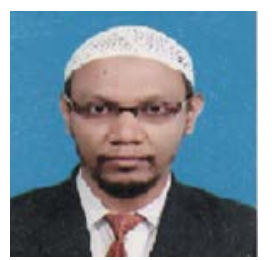

Rajamohamed did his MS in Power Electronics and Drives Engineering from Anna university, India, in 2004 and BE in Electrical and Electronics Engineering from M.K University, India, in 1998. He is now a lecturer of Electrical Engineering, King Faisal University. He has more than 14 years of academic experience. His research interest in power system stability, Renewable energy interconnection, Smart grid, etc.

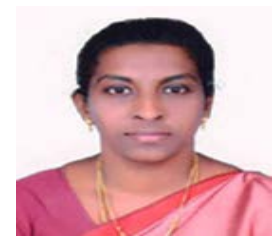

P. Aruna Jeyanthy received her B.E in Electrical and Electronics Engineering from A.C.C.E.T, Karaikudi, affiliated to Madurai Kamaraj University, Madurai in the year 1991. She obtained her M.E degree in Power Systems from Annamalai University, Chidambaram in the year 1993 and $\mathrm{PhD}$ degree in Electrical Engineering from Anna University, Chennai, in the year 2011 respectively. She is currently working as Head of the Department at School of Electrical and Electronics Engineering, Kalasalingam University, Tamilnadu, India.

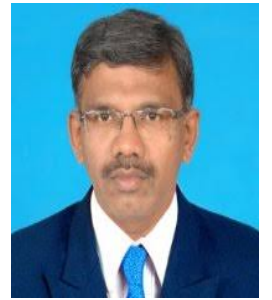

D. Devaraj completed his B.E and M.E in Electrical \& Electronics Engineering and Power System Engineering in the year 1992 and 1994, respectively, from Thiagarajar College of Engineering, Madurai. He obtained his Ph. D degree from IIT Madras, in the year 2001. He is currently working as Dean (academic) kalasalingham university, India. He has organized International, national Conferences and Seminars. He has Supervised several Ph. D, M.S and M.E thesis. His research interest includes Power system security, Voltage stability and Evolutionary Algorithm. 